\title{
Oyster (Crassostrea Virginica [Gmelin, 1791]) Mortality At Prolonged Exposures To High Temperature And Low Salinity
}

Melissa Southworth

Virginia Institute of Marine Science

M. Chase Long

Virginia Institute of Marine Science

Roger L. Mann

Virginia Institute of Marine Science

Follow this and additional works at: https://scholarworks.wm.edu/vimsarticles

Part of the Marine Biology Commons

\section{Recommended Citation}

Southworth, Melissa; Long, M. Chase; and Mann, Roger L., "Oyster (Crassostrea Virginica [Gmelin, 1791]) Mortality At Prolonged Exposures To High Temperature And Low Salinity" (2017). VIMS Articles. 303. https://scholarworks.wm.edu/vimsarticles/303 


\title{
OYSTER (CRASSOSTREA VIRGINICA [GMELIN, 1791]) MORTALITY AT PROLONGED EXPOSURES TO HIGH TEMPERATURE AND LOW SALINITY
}

\author{
MELISSA SOUTHWORTH, M. CHASE LONG AND ROGER MANN* \\ Virginia Institute of Marine Science, College of William and Mary, PO Box 1346, Gloucester Point, VA 23062
}

\begin{abstract}
Mortality of two size classes $(<35$ and $>35 \mathrm{~mm})$ of eastern oysters Crassostrea virginica when exposed to combinations of low salinity (1,2,3, and 4) for extended periods (up to 30 days) at summer water temperatures typical of the Virginia Chesapeake Bay subestuaries was examined. A critical salinity-temperature combination of less than two at greater than $28^{\circ} \mathrm{C}$ for more than $1 \mathrm{wk}$ exposure for oyster mortality is suggested. A review of limited historical salinity-temperature tolerance data suggest selection of local populations of oysters having differing salinity tolerances. Such selection may prove critical to persistence of low-salinity populations in the Chesapeake Bay subestuaries with projected climate change.
\end{abstract}

KEY WORDS: oyster, Crassostrea virginica, salinity tolerance

\section{INTRODUCTION}

The eastern oyster Crassostrea virginica (Gmelin, 1791) is remarkable in its range of both thermal and salinity tolerance, as demonstrated by its latitudinal range from the Canadian Maritimes to the Yucatan Peninsula, and from full seawater salinity habitats to the upper reaches of the major river systems and embayments of the east coast of North America. A general review of the geographical range of $C$. virginica can be found in Carlton and Mann (1996) and Carriker and Gaffney (1996). For a review of physiological tolerances, see Newell and Langdon (1996) and Shumway (1996). Oyster populations throughout the mid-Atlantic region have arguably undergone continuing selection for various physiological traits at local levels over the past six decades as first MSX (Haplosporidium nelsoni) and subsequently Dermo (Perkinsus marinus) extirpated formerly abundant populations from higher salinities in estuarine systems resulting in isolated local (within estuary) populations where former metapopulations (inclusive of many estuaries) existed. The subestuaries of the Chesapeake are such an example. The upriver, low-salinity sanctuary regions within these subestuaries form refuges for oysters with little tolerance to the diseases whose impacts are salinity dependent. Such refuges are of concern in the quest for long-term selection for increased disease tolerance, even resistance, in resident populations. On the other hand, these refuges may also present a selection site for individuals with increased tolerance to low salinity in combination with high temperatures.

The James River in the Virginia portion of the Chesapeake Bay remains both a substantial resource for the commercial oyster fishery and one of the few sites in the bay with stable shell habitat budgets (see Mann \& Powell 2007, Mann et al. 2009) to support robust future oyster populations in the absence of replenishment activity. The James River oyster reefs most subject to summer freshets (low-salinity events) are just downstream of a transitional zone where annual salinity values regularly vary from less than 1.0 in winter months to as high as 13 in late summer and fall months. A review of historical summer mortality data for the upper James River revealed the impacts of naturally occurring freshets of varying duration in the summer months. The most telling comparison is between observations in the summers of 1995 and 1996. In June, 1995,

*Corresponding author. E-mail: rmann@vims.edu DOI: $10.2983 / 035.036 .0205$ several weeks ${ }^{1}$ of salinity values of $2-4$ at $27^{\circ} \mathrm{C}-30^{\circ} \mathrm{C}$ resulted in high mortality at Deep Water Shoal in the James River (Fig. 1). By contrast, in the same period in 1996, low salinity was observed as temperature rose to $27^{\circ} \mathrm{C},{ }^{2}$ but river flow decreased providing high salinity for a period of several weeks, during the period that temperatures were maintained above $27^{\circ} \mathrm{C}$. When river flow had again increased, resulting in lower salinities $(<2)$, water temperature was falling below $25^{\circ} \mathrm{C}$ with the seasonal decrease toward the fall months. Observed oyster mortality at Deep Water Shoal in 1996 was low, comparable to other years in the long-term $(>30 \mathrm{y})$ record. The distinguishing feature of the 1995 versus 1996 field observations is a prolonged period (34 wk) at greater than $27^{\circ} \mathrm{C}$ and less than two salinity at Deep Water Shoal, suggesting that this temperature-salinity combination is critical to inducing large-mortality events. A summer mortality event was also observed at Deep Water Shoal in 2003 when temperature-salinity-river flow combinations were, with the exception of $1 \mathrm{wk}$, between $26^{\circ} \mathrm{C}$ and $30^{\circ} \mathrm{C}$ at salinity values less than three from June 22 to July 16, 2003. As with 1995 observations, mortality events appear to be related to prolonged periods (3-4 wk), with temperatures greater than $27^{\circ} \mathrm{C}$ and salinity less than two. Mann and Evans (1998) presented a mathematical relationship between salinity at Deep Water Shoal and water flow at the USGS river gauge station 02037500

${ }^{1}$ Salinity-temperature combinations for 1995 were as follows: June 29: 4, $27.3^{\circ} \mathrm{C}$; July $5: 2,30^{\circ} \mathrm{C}$; July $12: 4,29.5^{\circ} \mathrm{C}$; July $19: 2,30.2^{\circ} \mathrm{C}$. River flow at Richmond during this same period increased from $126 \mathrm{~m}^{3} \mathrm{sec}^{-1}$ on June 23 to $2,149 \mathrm{~m}^{3} \mathrm{sec}^{-1}$ on June 30 . River flow had decreased to $209 \mathrm{~m}^{3} \mathrm{sec}^{-1}$ by July 14, but between June 24 and July 3, it remained above $651 \mathrm{~m}^{3} \mathrm{sec}^{-1}$ (range of 677-2,149 $\mathrm{m}^{3} \mathrm{sec}^{-1}$ ) and with the exception of 1 day remained above $283 \mathrm{~m}^{3} \mathrm{sec}^{-1}$ from July 4 to July 13 . From a review of many years of data, it is rare that summer river flows exceed $283 \mathrm{~m}^{3} \mathrm{sec}^{-1}$ and when it does, it is usually only sustained for a few days, not several weeks.

${ }^{2}$ Data for 1996 were as follows: salinity was consistently 2 for $3 \mathrm{wk}$ (June 4 to June 19), with temperature ranging from $21.3^{\circ} \mathrm{C}$ to $28.2^{\circ} \mathrm{C}$. Salinity then increased and remained above 4 until mid-September. Salinity again decreased and ranged between 0 and 4 from September 11 to October 2 by that time temperature had decreased to less than $26^{\circ} \mathrm{C}$ and continued to decrease throughout the low-salinity event. The second low-salinity event was the result of Hurricane Fran; there was a total of $40 \mathrm{~cm}$ of rain in Western Virginia, at which time river flow increased from $180 \mathrm{~m}^{3} \mathrm{sec}^{-1}$ on September 5 to $4,021 \mathrm{~m}^{3} \mathrm{sec}^{-1}$ on September 8 (2 days after Hurricane Fran made landfall). This was a very large pulse of water, but river flow was back to less than $283 \mathrm{~m}^{3} \mathrm{sec}^{-1}$ by September 15 . 


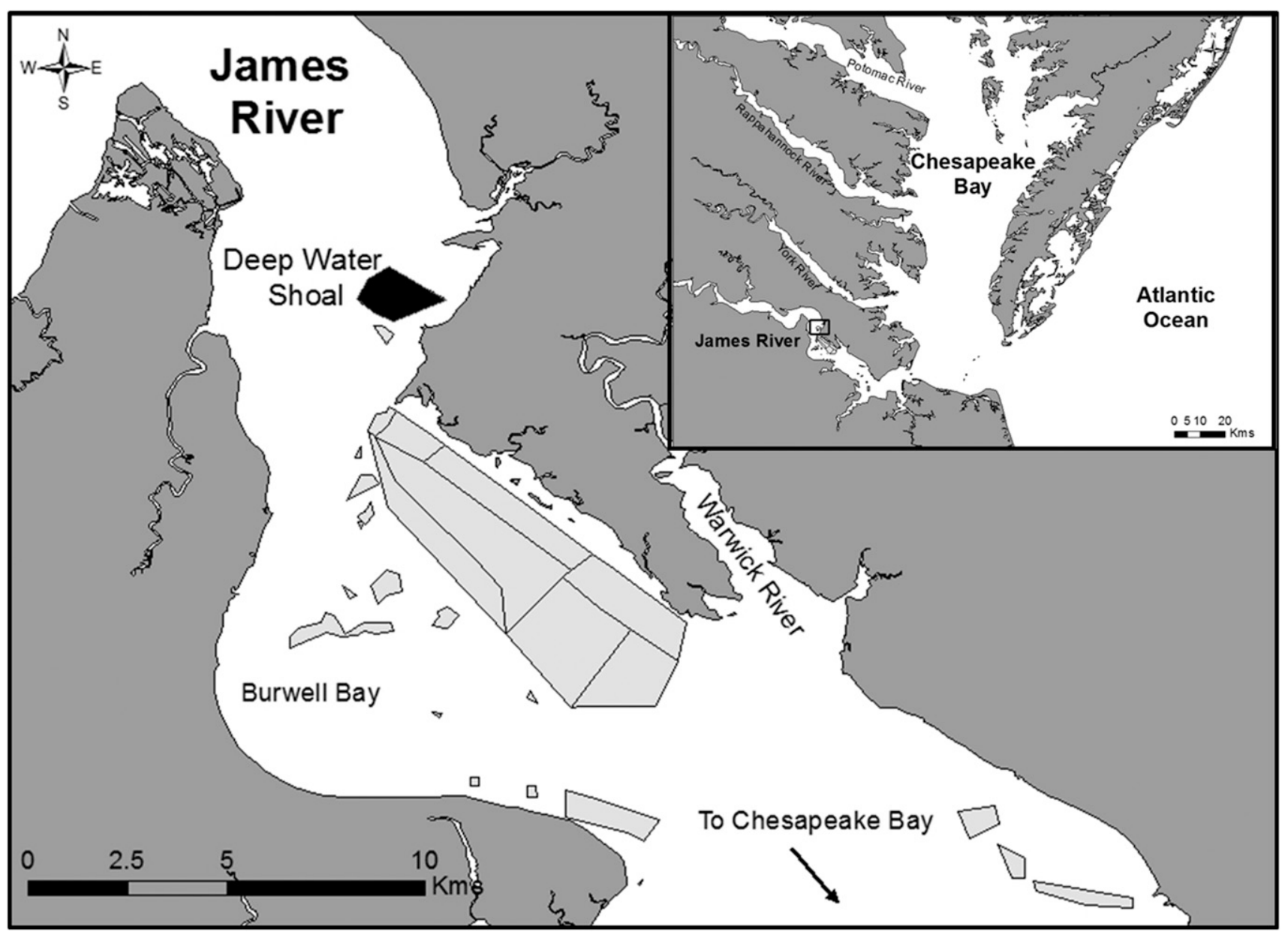

Figure 1. Map showing the location of Deep Water Shoal reef (shaded in black), near the uppermost limit of oyster distribution in the James River, VA.

in Richmond Virginia, located approximately $90 \mathrm{~km}$ upstream. River flows in excess of $283 \mathrm{~m}^{3} \mathrm{sec}^{-1}$ at USGS station 02037500 result in salinity of less than two and often less than one at Deep Water Shoal. As an example, in both 1995 and 2003, both years that experienced high summer mortalities as previously mentioned, river flow was consistently greater than $283 \mathrm{~m}^{3} \mathrm{sec}^{-1}$ for prolonged periods when temperatures were increasing above $27^{\circ} \mathrm{C}$. From June 24 to July 13, 1995, with the exception of 1 day, river flow varied between 286 and $2,149 \mathrm{~m}^{3} \mathrm{sec}^{-1}$. In 2003, river flow remained above $283 \mathrm{~m}^{3} \mathrm{sec}^{-1}$ for most of May and June, and varied between 303 and $1,357 \mathrm{~m}^{3} \mathrm{sec}^{-1}$ from July 3 to July 9 .

Summer freshets present a significant mortality threat to oyster populations in upriver locations. An improved understanding of this threat is thus desirable in terms of both predicting ecological impacts and managing commercial exploitation. The objective of the current study was to critically examine the time course of high water temperature-low salinity combinations in determining high cumulative mortality rates in oysters in an experimental setting, and to compare these findings with historical field observations.

\section{MATERIALS AND METHODS}

The distribution and population biology of oysters in the James River over recent decades have been described in Mann et al. (2009). A summary of river flow and water temperature in this riverine system is also provided in Mann et al. (2009). A comprehensive description of environmental conditions throughout the summer months coincident with oyster recruitment is given in a series of annual reports available at (www. vims.edu/research/units/labgroups/molluscan_ecology/publications/ reports). Typical summer temperatures and salinities in this region may be as high as $31^{\circ} \mathrm{C}$ and 8 , respectively. The design of this study was a prolonged exposure of two size classes of oysters to ambient summer water temperature at salinity values of 1, 2, 3, and 4 , with daily monitoring of survival/mortality.

The experiment was carried out in summer 2016. Oysters were collected with an oyster hand scrape from Deep Water Shoal $\left(37.1488^{\circ} \mathrm{N}, 76.6356^{\circ} \mathrm{W}\right)$ in the upper section of Burwell Bay in the James River (Fig. 1) on June 29. The oysters were collected at a depth of $1.2-3.5 \mathrm{~m}$. Water temperature at the site on the day of collection was $26.5^{\circ} \mathrm{C}$ and salinity was 4.5 . Care was taken to insure that both yearling $(<35 \mathrm{~mm}$ shell length, oysters presumed to be recruited in summer 2015) and older (>35 mm shell length, 2 y and older) oysters were collected to allow examination of both size/age ranges in the experimental trials. The oysters were transported in insulated boxes (transit time $<2 \mathrm{~h}$ ) and transferred to running seawater $(20 \mathrm{~L} / \mathrm{min})$ in a holding tank $(200 \mathrm{~cm} L \times 75 \mathrm{~cm} W \times 75 \mathrm{~cm} D)$ at the Virginia Institute of Marine Science (VIMS: $37.2483^{\circ} \mathrm{N}, 76.5006^{\circ} \mathrm{W}$ ) at 


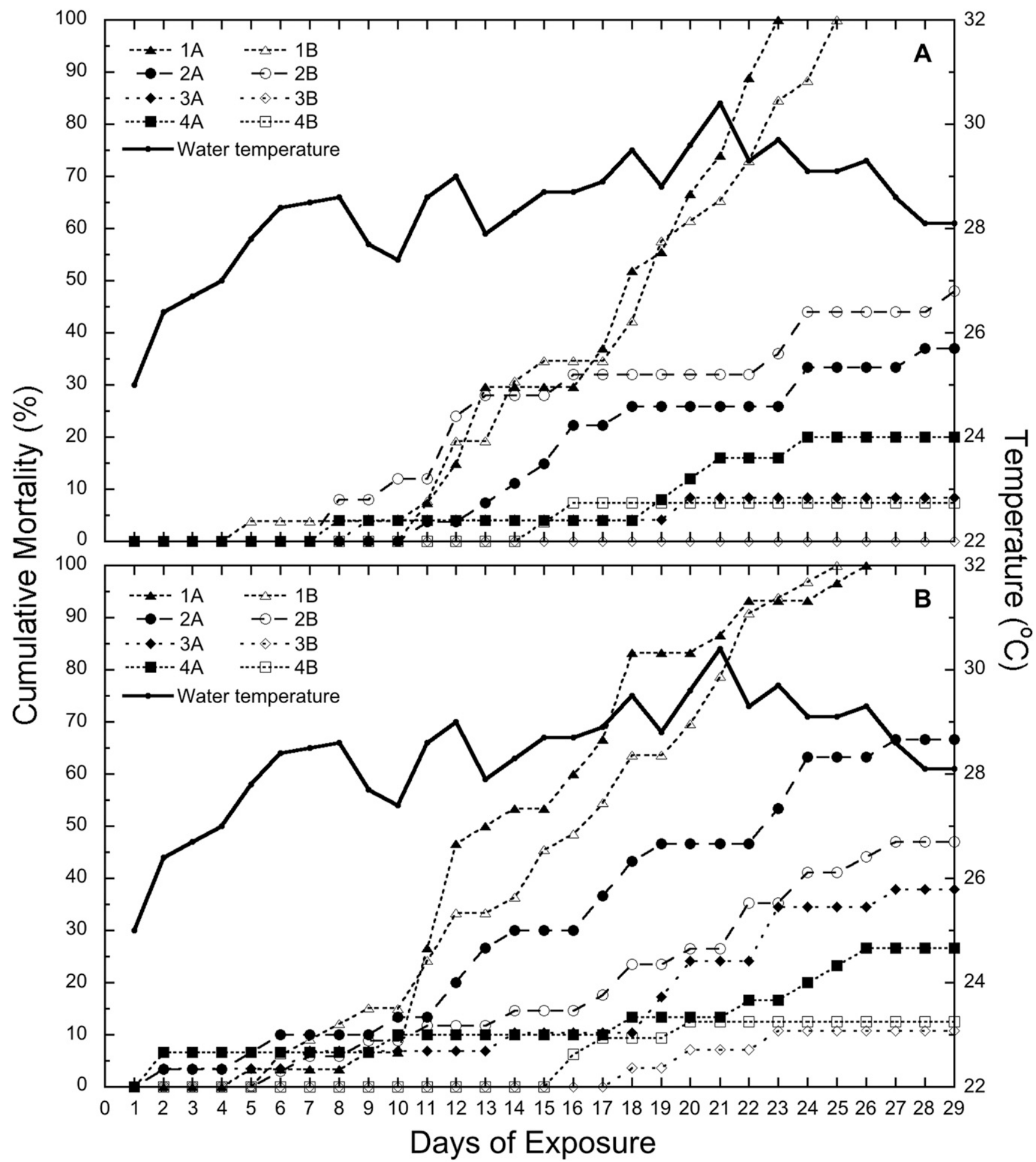

Figure 2. Cumulative mortality of small ((A); $<35 \mathrm{~mm}$ shell length) and large ((B); $>35 \mathrm{~mm}$ shell length) oysters exposed to salinities of 1 (1A and $1 \mathrm{~B}), 2$ (2A and $2 \mathrm{~B}), 3$ (3A and 3B), and 4 (4A and 4B). The first vertical $(Y)$ axis is cumulative mortality as a percentage of the starting population size. The second vertical axis $(Y 2)$ is water temperature $\left({ }^{\circ} \mathrm{C}\right)$.

$25.8^{\circ} \mathrm{C}$ and 18.1 salinity. Intake water to the holding tank was pumped from a depth of $2 \mathrm{~m}$ in the York River, VA. The oysters were left overnight in running seawater to ensure that any animals chosen for the experimental challenge were live and actively pumping. The intake to the holding tank was continuously monitored for temperature throughout the holding period and the subsequent experimental period, when the same tank was used as a water bath for the individual treatments. In addition, daily or more frequent measurements were made of temperature and salinity in the experimental tanks throughout the course of the experiment using a handheld electronic probe (YSI Pro2030). 


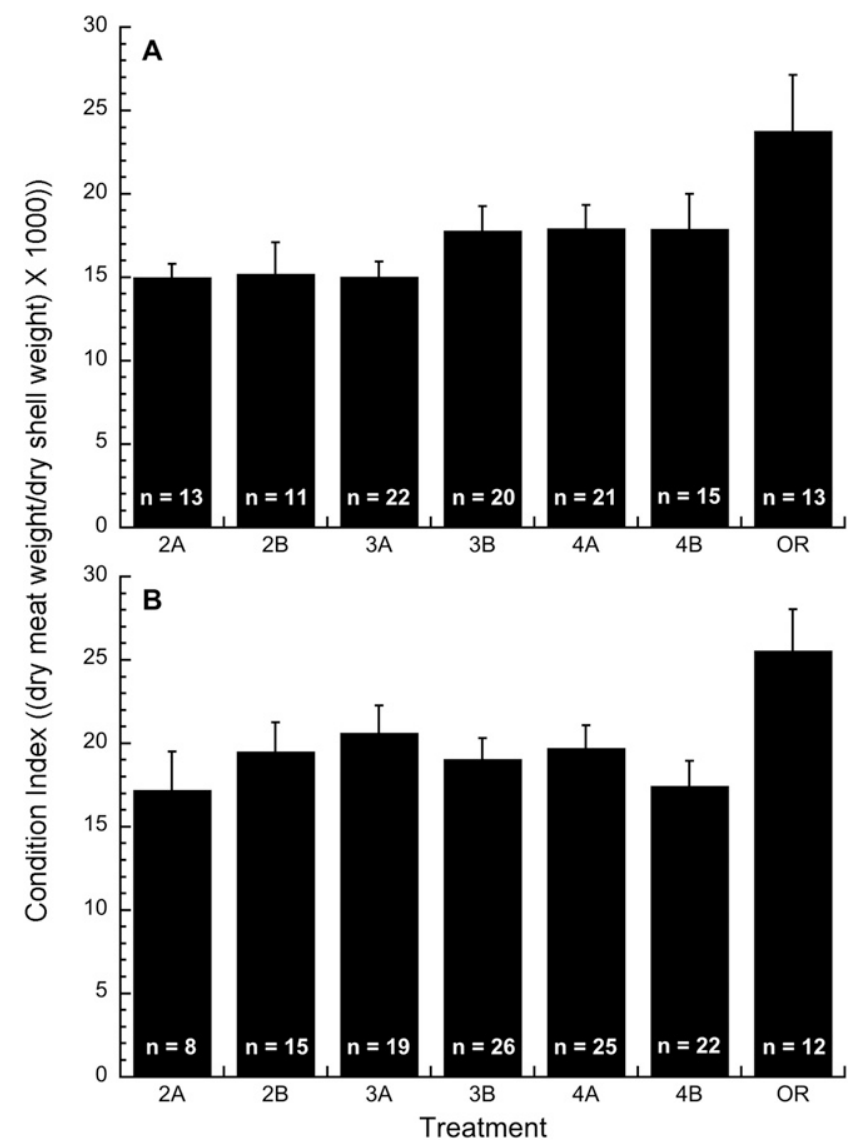

Figure 3. Mean CI of small (A) and large (B) oysters from the treatment groups that had animals remaining at the end of the experiment along with oysters from the original collection (OR) for comparison. The number of animals included in each mean calculation is denoted by " $n$." Error bars represent standard error of the mean.

At $24 \mathrm{~h}$ after collection, the oysters were again examined, and an initial subsample of 25 oysters was taken and frozen for subsequent determination of condition index (CI) [Walne \& Mann (1975) in units of (dry meat weight $\times 1000 /$ dry shell weight)]. The experimental design required that water temperature be maintained at ambient in all treatments. Thus, temperature would fluctuate over time as for the York River system, and would be expected to reach $30^{\circ} \mathrm{C}$ by mid to late July. Individual oysters were selected at random from the source collection and divided into eight populations that contained both yearling (hereafter small, $<35 \mathrm{~mm} \mathrm{SL}$ ) oysters and older (hereafter large, $>35 \mathrm{~mm} \mathrm{SL}$ ) oysters. The eight populations were randomly assigned to four pairs. Each pair was designated as replicates (A and B) for a chosen salinity; targets for salinity were 1, 2, 3, and 4 in static (not flow through) containers (68-L volume), to be maintained at these salinity values for the duration of the experiment. The protocol required that salinity be reduced gradually from holding salinity (18) at the rate of 2 per day to the target salinity to minimize stress from rapid salinity change; this is equivalent to gradual changes in the upper James as a large freshet event in the watershed is translated into increased flow and thus decreased the salinity.

Salinity management for the eight experimental populations was as follows: "Stock" dilutions (151 L) of ambient seawater with fresh water to obtain desired salinities (1, 2, 3, and 4) were made daily and allowed to sit for $24 \mathrm{~h}$ with aeration in the holding tank (temperature equilibration) before daily water changes. The rate for salinity "step down" for all populations was 2 per day to 4. All eight experimental populations were at 4 by July 6 . On July 7, two populations were reduced to a salinity of 3 and four populations to a salinity of 2 , thus producing two populations at 4 , two at 3 , and four at 2 . On July 8 , two populations were reduced from a salinity of 2 to 1 . Thus, by July 8 , two populations were at each of the four desired salinities, that is, 1,2, 3, and 4. No mortality of oysters was observed to this time. The numbers of oysters in each treatment at this time were as follows: 1A: 27 small + 30 large; 1B: 26 small + 33 large; 2A: 27 small + 30 large; 2B: 25 small + 34 large; 3A: 24 small +29 large; $3 \mathrm{~B}: 26$ small +28 large; 4A: 25 small + 30 large; 4B: 27 small + 32 large.

Throughout both the "step down" period and the subsequent experimental period, the continuous intake temperature records to the holding tank were supplemented by daily or more frequent measurements of both temperature and salinity in the experimental tanks using a handheld electronic probe (YSI Pro2030).

Beginning on July 8 , once all oysters were at their final experimental salinity, the oyster populations were examined for mortality on a daily basis as water changes were performed. Dead oysters were measured (nearest SL) upon removal. This protocol was maintained through August 5, at which time all of the oysters in treatments $1 \mathrm{~A}$ and $1 \mathrm{~B}$ (salinity =1) had died. All remaining live oysters in the other salinity treatments were frozen for subsequent estimation of CI using the methods in Walne and Mann (1975) as described earlier.

\section{RESULTS}

The oysters actively fed throughout the trial period as evidenced by the presence of fecal material at daily water changes. Cumulative mortality data are summarized in Figure 2A (small, $<35 \mathrm{~mm}$ SL oysters) and Figure 2B (large, $>35 \mathrm{~m} \mathrm{SL}$ oysters) with days of exposure, rather than date, on the horizontal $(X)$ axis. The first vertical $(Y)$ axis is cumulative mortality as a percentage of the starting population size. The second vertical axis is water temperature $\left({ }^{\circ} \mathrm{C}\right)$.

Between days 1 and 7, water temperature rose from $25^{\circ} \mathrm{C}$ to $28.5^{\circ} \mathrm{C}$. Less than $10 \%$ cumulative mortality was observed in all salinity treatments for both size ranges. Between days 8 and 14 , water temperature oscillated in the $28^{\circ} \mathrm{C}-29^{\circ} \mathrm{C}$ range. Cumulative mortality at a salinity of 1 (triangles in Fig. 2) rose to $30 \%$ for small oysters, and from $36 \%$ to $53 \%$ for large oysters. Cumulative mortality at 2 (circles in Fig. 2) varied between $10 \%$ and $30 \%$ for small oysters, and $15 \%-30 \%$ for large oysters. Cumulative mortality at salinities of 3 and 4 (diamonds and squares, respectively, in Fig. 2) remained between $0 \%$ and $4 \%$ for small oysters and $0 \%$ and $10 \%$ for large oysters, with no distinction between the 3 and 4 salinity treatments. Between days 15 and 21 , water temperature rose from $28.7^{\circ} \mathrm{C}$ to $30.4^{\circ} \mathrm{C}$. Cumulative mortality at a salinity of 1 rose to between $65 \%$ and $74 \%$ for small oysters, and between $79 \%$ and $87 \%$ for large oysters. Cumulative mortality at 2 was at $26 \%-32 \%$ for small oysters, and $26 \%-47 \%$ for large oysters. Cumulative mortality at salinities of 3 and 4 remained between $0 \%$ and $16 \%$ for small oysters and $7 \%$ and $24 \%$ for large oysters with no distinction between the 3 and 4 salinity treatments. Between days 22 and 29, 


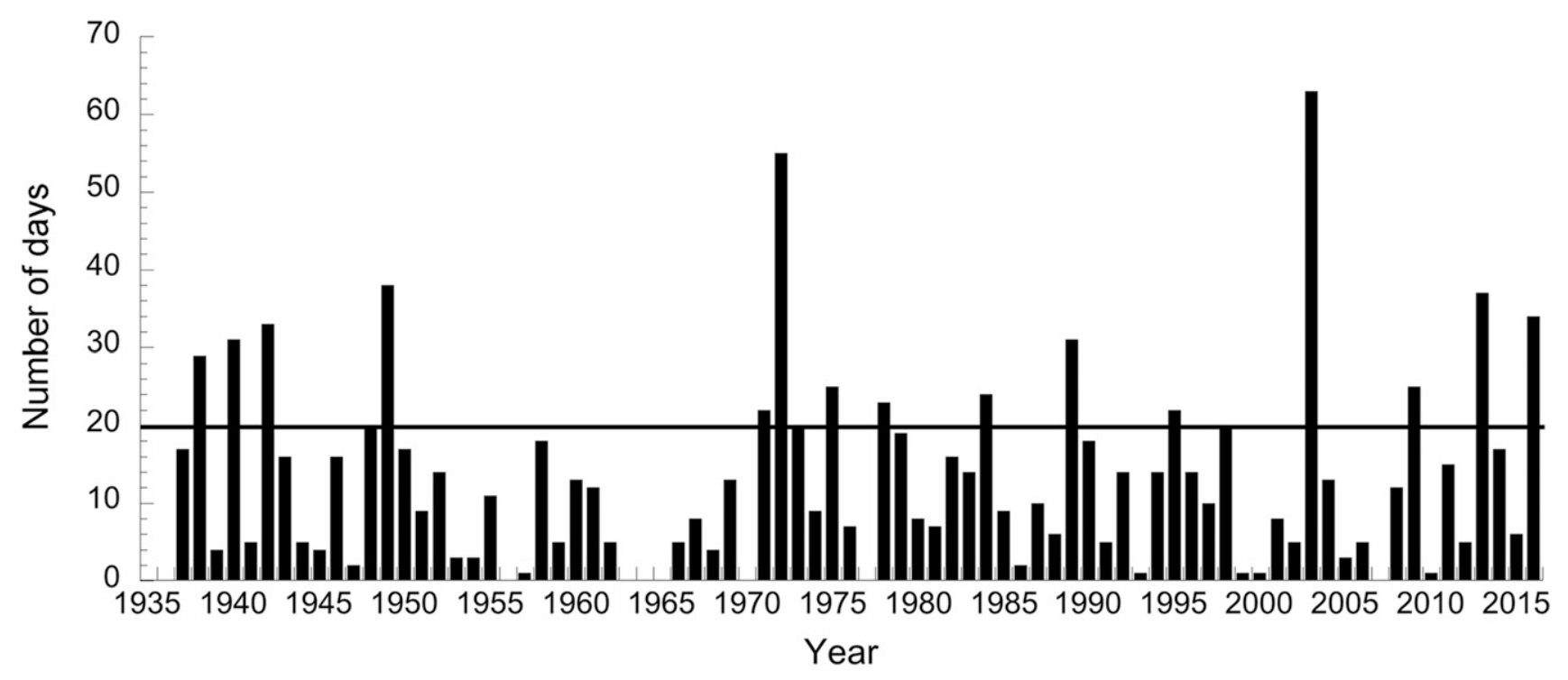

Figure 4. Total number of days from May 1 to August 31 when river flow was greater than $283 \mathrm{~m}^{3} \mathrm{sec}^{-1}$ in the period from 1935 to 2016 . Solid black line represents more than 20 days with river flow greater than $283 \mathrm{~m}^{3} \mathrm{sec}^{-1}$.

water temperature decreased from $29.3^{\circ} \mathrm{C}$ to $28.1^{\circ} \mathrm{C}$. Cumulative mortality at a salinity of 1 rose to $100 \%$ in both size ranges and replicates. This occurred in the small oysters at days 23 and 25 , and by days 25 and 26 in the large oysters. By day 29, cumulative mortality at 2 was at $37 \%$ and $48 \%$ for small oysters and at $47 \%$ and $67 \%$ for large oysters. By day 29 , cumulative mortality at salinities of 3 and 4 was between $0 \%$ and $20 \%$ for small oysters and between $11 \%$ and $38 \%$ for large oysters, with no distinction between the 3 and 4 salinity treatments.

This time sequence of observations can be expanded to a general series of statements concerning cumulative mortality. An exposure of 7 days or less to a salinity of 1 , and less than $28.5^{\circ} \mathrm{C}$ causes negligible mortality of small oysters and only marginally higher mortality of large oysters. As temperature increases to $28.5^{\circ} \mathrm{C}$ and above with exposure more than 7 days, mortality at a salinity of 1 increases substantially in both size ranges, notably in the larger oysters. Mortality at a salinity of 2 under the same conditions approaches that at 1 and is higher than at 3 and 4 . This combination of low salinity and exposure period would be expected to cause substantial mortality of oysters in the field.

Increasing water temperature to $29^{\circ} \mathrm{C}-30^{\circ} \mathrm{C}$ with a salinity of 1 results in very high mortality. Even at a salinity of 2, an excess of $30 \%$ mortality can be expected. At a salinity of 3-4, mortality increases notably above that observed at lower temperature, although there is no distinction in the mortality rate between 3 and 4 . With subsequent decreasing water temperature, mortality continues at a salinity of 1 to complete population loss before the end of the 30-day experimental period. At a salinity of 2, mortality rate (number per unit time) decreases, but cumulative mortality (total number dead since the beginning of the trial) continues to increase. If a salinity of 3-4 is considered as a long-term summer minimum (i.e., no freshets) value, then the associated natural mortality rate is expected to be variable, more so in larger animals.

Condition index data are summarized in Figure 3. With respect to small oysters, the $2 \mathrm{~A}$ and $2 \mathrm{~B}$ treatments had the lowest terminal CI; $4 \mathrm{~A}$ and $4 \mathrm{~B}$ terminal values were higher, with $3 \mathrm{~A}$ and $3 \mathrm{~B}$ values in between. Notably, all were lower than the original value from the time of initiation of the trial. With respect to large oysters, there was no consistent pattern among the terminal values for salinities of 2, 3, and 4 treatments but, again, all were lower than the original value from the time of initiation of the trial. The lower CI values indicate that oysters in all of the low-salinity treatments were stressed compared with original field collections, even though the mortality of the experimental population was not observed at the end of the trial. This is important because oysters in poor condition are susceptible to additional stressors other than low salinity. For example, if a low-salinity event is compounded with a lowoxygen event, then mortality rates in excess of those described in Figure 2 should be expected.

\section{DISCUSSION}

Shumway (1996) summarized a wide range of prior reports of low salinity and freshet-related mortality in oysters. Engle (1946) describes a freshet in the late March of 1945 in the upper Chesapeake Bay ("head of the Bay," north of Chester River) followed by a short period of increased salinity and another freshet in May 1945. The following summer period was characterized by salinity between 3 and 6 until the end of August, followed by a short period of salinity of 9 through September, and subsequent lower salinities between 5 and 7 for the remainder of the year. Oysters subjected to these conditions exhibited $50 \%-92 \%$ mortality by the spring of 1946 . May (1972) reported high mortalities of oysters in Mobile Bay, AL, when exposed to a salinity of less than two for several weeks in the months of April and May; however, no accompanying values of water temperature were given. Loosanoff (1953) observed $100 \%$ mortality in experimental studies of both 4mo-old and 4-y-old oysters from Long Island Sound, CT, when they were exposed to a salinity of 3 at $23^{\circ} \mathrm{C}-27^{\circ} \mathrm{C}$ for 15 days. At a salinity of 5 , mortalities of $70 \%$ were observed after 13 days of exposure, and $75 \%$ after 30 days. Both of these observed mortality values are higher than those observed in the current study. The exposures examined by Loosanoff (1953) are comparable to the earlier described field conditions in the James 
River in 1996 at less than $28^{\circ} \mathrm{C}$, when very limited mortality was observed. Andrews et al. (1959) examined the low salinity and high temperature tolerance of James River oysters when they were maintained in spring conditions of low salinity in combination with low temperature. Conditioned oysters were able to withstand long periods of low salinity, even when the temperature increased to between $25^{\circ} \mathrm{C}$ and $27^{\circ} \mathrm{C}$. By contrast, James River oysters taken from higher-salinity water, that were not preconditioned to low salinity, were less resilient and exhibited similar mortalities to that reported by Loosanoff (1953), being unable to tolerate more than 1-2 wk in fresher water. Previously mentioned field observations in the James River in 2003 are inconsistent with Andrews et al. (1959) reports in that the spring of 2003 was very wet, with river flow at the Richmond USGS station generally greater than $283 \mathrm{~m}^{3} \mathrm{sec}^{-1}$ from February through the end of June (with the exception of a few weeks in April 2003), yet substantial summer mortality was observed.

Despite the inconsistency between the data of Andrews et al. (1959) and the current study, there is subtle evidence for selection with local populations of oysters having differing salinity tolerances. Figure 4 summarizes the number of days per year when river flow exceeded $283 \mathrm{~m}^{3} \mathrm{sec}^{-1}$ for the months of May through August in the period 1935 to 2016 (81 y). The summer month limitation thus includes periods of low salinity in combination with probable high water temperature, which is proffered as a selective pressure, while excluding winter-spring freshets at low temperatures when physiological activity and mortality are minimal. For convenience, a bar at 20 days is added to the plot in Figure 4; this corresponding to cumulative mortality greater than $50 \%$ in several treatments portrayed in Figure 2. Fifteen of the $81 \mathrm{y}$ had more than 20 days at summer river flows greater than $283 \mathrm{~m}^{3} \mathrm{sec}^{-1}$. Half of the years had more than 10 days river flow greater than $283 \mathrm{~m}^{3} \mathrm{sec}^{-1}$. Despite these challenging conditions, the oyster population at Deep Water
Shoal has persisted throughout a lengthy period of annual stock monitoring (see Mann et al. 2009, VIMS annual dredge surveys 1994 present at http:/www.vims.edu/research/units/labgroups/ molluscan_ecology/publications/topic/annual_reports/index.php and graphic summaries from patent tong surveys 1998 - present at http://cmap2.vims.edu/VOSARA/viewer/VOSARA.html) with consistent presence of several year classes indicating survival through frequent salinity challenges.

The upper Burwell Bay region of the James River (Fig. 1) has long been noted as a region of high recruitment for oysters; complex circulation within this reach of the river tends to retain larvae that originate within it (see Mann \& Evans 1998), yet it faces an uncertain future. The extent of land subsidence throughout this region of the Virginia coastal plain remains a subject of active debate, although it is considered to be substantial (see discussion in Davis 1987). Dredging of the entrance to Chesapeake Bay and the James River, respectively, to facilitate access of large commercial vessels to the Port of Hampton Roads and Richmond, downstream and upstream, respectively, of the study site, increases the flow of high-salinity bottom water upstream to the region of interest. Countering the high-salinity influences of subsidence and dredging is the predicted increase in summer temperature and reapportioning of the annual rainfall to increased summer storms with associated freshet events in the mid-Atlantic states (National Climate Assessment, nca2014.globalchange.gov). The future expectation for fragile up-estuary populations is that of increased challenge by both higher summer temperature and periodic coincident freshets associated low salinity.

\section{ACKNOWLEDGMENTS}

This paper is Contribution No. 3640 of the Virginia Institute of Marine Science, College of William and Mary.

\section{LITERATURE CITED}

Andrews, J. D., D. Haven \& D. B. Quayle. 1959. Freshwater kill of oysters (Crassostrea virginica) in James River, Virginia. Proc. Natl. Shellfish. Assoc. 49:29-49.

Carlton, J. T. \& R. Mann. 1996. Transfers and world-wide introductions. In: Kennedy, V. S., R. I. E. Newell \& A. F. Eble, editors. The eastern oyster: Crassostrea virginica. College Park, MD: University of Maryland Sea Grant Press. pp. 691-706.

Carriker, M. R. \& P. M. Gaffney. 1996. A catalogue of selected species of living oysters (Ostreacea) of the world. In: Kennedy, V. S., R. I. E. Newell \& A. F. Eble, editors. The eastern oyster: Crassostrea virginica. College Park, MD: University of Maryland Sea Grant Press. pp. 1-18.

Davis, G. H. 1987. Land subsidence and sea level rise on the Atlantic Coastal Plain of the United States. Environ. Geol. Water Sci. 10:6780.

Engle, J. B. 1946. Commercial aspects of the upper Chesapeake Bay oyster bars in light of the recent oyster mortalities. Proc. Natl. Shellfish. Assoc. 1946:42-46.

Loosanoff, V. L. 1953. Behavior of oysters in water of low salinities. Proc. Natl. Shellfish. Assoc. 43:135-151.

Mann, R. \& D. A. Evans. 1998. Estimation of oyster, Crassostrea virginica, standing stock, larval production and advective loss in relation to observed recruitment in the James River, Virginia. $J$. Shellfish Res. 17:239-254.

Mann, R. \& E. N. Powell. 2007. Why oyster restoration goals in the Chesapeake Bay are not and probably cannot be achieved. $J$. Shellfish Res. 26:905-917.

Mann, R., M. Southworth, J. M. Harding \& J. A. Wesson. 2009. Population studies of the native oyster Crassostrea virginica (Gmelin) in the James River, Virginia, USA. J. Shellfish Res. 28:193-220.

May, E. B. 1972. The effect of floodwater on oysters in Mobile Bay. Proc. Natl. Shellfish. Assoc. 62:67-71.

Newell, R. I. E. \& C. J. Langdon. 1996. Mechanisms and physiology of larval and adult feeding. In: Kennedy, V. S., R. I. E. Newell \& A. F. Eble, editors. The eastern oyster: Crassostrea virginica. College Park, MD: University of Maryland Sea Grant Press. pp. 185-229.

Shumway, S. E. 1996. Natural environmental factors. In: Kennedy, V. S., R. I. E. Newell \& A. F. Eble, editors. The eastern oyster: Crassostrea virginica. College Park, MD: University of Maryland Sea Grant Press. pp. 467-513.

Walne, P. R. \& R. Mann. 1975. Growth and biochemical composition in Ostrea edulis and Crassostrea gigas. In: Barnes, H., editor. Proceedings of the 9th European Marine Biology Symposium, Aberdeen University Press, Aberdeen. pp. 587-607. 